\title{
EchoGéo
}

25 | 2013

Moyen-Orient : espaces et passeurs du changement

\section{Utopia or the Anti-Tahrir. The worst of all worlds in the fiction of A. K. Towfik}

\section{Delphine Pagès-El Karoui}

\section{(2) OpenEdition \\ $\checkmark$ Journals}

Electronic version

URL: https://journals.openedition.org/echogeo/17748

DOI: 10.4000/echogeo.17748

ISSN: 1963-1197

\section{Publisher}

Pôle de recherche pour l'organisation et la diffusion de l'information géographique (CNRS UMR 8586)

\section{Electronic reference}

Delphine Pagès-El Karoui, "Utopia or the Anti-Tahrir. The worst of all worlds in the fiction of A. K. Towfik", EchoGéo [Online], 25 | 2013, Online since 12 August 2019, connection on 11 August 2021 URL: http://journals.openedition.org/echogeo/17748 ; DOI: https://doi.org/10.4000/echogeo.17748

This text was automatically generated on 11 August 2021

EchoGéo est mis à disposition selon les termes de la licence Creative Commons Attribution - Pas d'Utilisation Commerciale - Pas de Modification 4.0 International (CC BY-NC-ND) 


\title{
Utopia or the Anti-Tahrir. The worst of all worlds in the fiction of A. K. Towfik
}

\author{
Delphine Pagès-El Karoui
}

\section{REFERENCES}

Towfik, A. K.

Utopia,

2013. Paris, Ombres noires, 182 p.

Citations from the novel in this article are principally drawn from the 2013 French translation, although an English translation of the novel also exists.

1 If there is a symbol par excellence of the socio-economic changes spurred by globalization in Egypt, it is surely the gated community. Since the middle of the 1990s, their unbridled proliferation in Cairo's peripheries, on public land sold for a song to private developers, has generated abundant academic work showing how neoliberal logics have resulted in the city's privatization and urban fragmentation (Bouhali, 2008; Denis, 2006; Florin, 2012). Egyptian author Ahmed Khaled Towfik makes use of these spaces as a means to denounce the accentuation of social inequalities and the disappearance of the middle classes in a futuristic novel published prior to the revolutionary movement, in 2008. Utopia ${ }^{1}$ takes its title from a gated compound on the Mediterranean coast where rich, westernized Egyptians live hidden away while the rest of the miserable population languishes in a territory that has been reduced to a giant slum. The story, which takes place in 2023, involves a young couple from Utopia deciding to try to overcome their boredom by making a foray into this blighted area to kill a poor person and bring back one of his limbs as a trophy.

2 Born in 1962, Ahmed Khaled Towfik, who still teaches medicine at the University of Tanta, was previously known as an author of literature for adolescents, particularly 
horror and science fiction. With Utopia, which became a bestseller in Egypt, he acquired the status of a recognized novelist (Jacquemond, 2013). ${ }^{2}$ Utopia is one of the leading novels of a new literary space in Egypt which, since the publication of The Yacoubian Building by Alaa Al-Aswany in 2002, has seen the rise of a number of bestsellers appealing to a young, educated, urban, often female readership. It is also a marker of this literature's globalization, since it was published in English in 2011 by Bloomsbury Qatar Publishing Foundation, a British-Qatari joint venture created in 2008 for the purpose of promoting Arabic literature to a new global standing (Jacquemond, 2013).

In comparison to other successful authors of his generation, such as Alaa Al-Aswany or Khaled Al-Khamissi, the author of Taxi and Noah's Ark, who have also significantly criticized Egyptian society, Towfik makes use of a literary device that is uncommon in Egyptian literature, the dystopia ${ }^{3}$. Contrary to the utopia, which since Thomas More's work by that name embodies an imaginary ideal society, a dystopia represents the worst of all possible worlds. As he puts it clearly in a disclaimer in the text, ${ }^{4}$ Towfik seeks to alarm Egyptians at the state of their society and the dark future that may result. The final revolt on which the novel closes has been regarded, with hindsight, as premonitory of the revolutionary process. Might Utopia be regarded as a visionary novel?

\section{The Two Worlds}

The book opens with a scene in which a poor wretch who attempted to enter Utopia illegally is shot to death from a helicopter. Towfik thus describes two strictly separated worlds. On the one hand is Utopia, surrounded by gates and barbed wire, and protected by retired US Marines making surveillance rounds and stopping anyone without authorization from entering. Inside, the opulent city is divided between the Gardens quarter where schools and places of prayer (Mosques, Churches and Synagogues) are located, and the Malls quarter, with its giant shopping malls and villas. Connected as it is with the world, Utopia even has an interior airport so that its residents can avoid having to cross the poor area and risk being lynched along the way. The community has its own newspapers, laws and courts, and is governed by a council of wise men, presided over by the most eminent businessmen among them. The only cleavage that seemingly still persists inside Utopia is between the generations: the spoiled youth of Utopia are idle and depraved, partaking openly and excessively in sex and drugs, whereas their parents still have the hypocrisy to hide their vices behind the veil of respectability and religion. Whereas the youth no longer believe in anything, the 'old folks' cling to religion out of fear of 'losing what distinguishes them, and finding themselves abroad' (p.22).

The other world is one of absolute alterity, as those who do not live in Utopia are referred to as "the Others". The description of the city of the poor is apocalyptic: reduced to a giant slum, it no longer has any public services. The electricity and sewer networks have ceased to function, the metro has been abandoned and cinemas have disappeared, the world itself having been erased from people's memories. The inhabitants have been reduced to an animal-like state, struggling against one another to find food and avoid illness, or seeking escape from their miserable condition through alcohol, drugs, or religion. One of the only opportunities to find work is in Utopia, where they carry out the most drudgerous tasks and are tolerated during the day, but 
must leave at night, on a bus that carries them home. Whereas in the decade when Towfik was writing, marriage was often delayed for financial reasons and there was a religious injunction against premarital sexual relations, in 2023, sex has become very commonplace. Another change relative to the Egypt of 2008 is the disappearance of religious divisions: shared poverty has paradoxically created equality between the religions. The situation of women, on the other hand, has not improved, since they remain at the mercy of men, and are forced to resort to theft or prostitution. ${ }^{5}$

Despite their separateness, the two worlds are connected by one commonality: violence, a symbol of their dehumanisation. But since when has Egypt been transformed in this way?

\section{The decade when the middle class disappeared}

7 The answer to this question is given by Gaber, the young man who helps the protagonists to return home to Utopia. He describes the disappearance of the middle class over the course of the first decade of the $21^{\text {st }}$ century, in the context of very high levels of poverty and unemployment: the upper class 'prevailed over what was left of the middle class and society divided itself into two. [...] There were frightening indicators, everyone should have seen it coming' (p.128). The turning point came with the successive collapse of the pillars of the Egyptian economy: tourism, which slowed and became insufficient to keep the economy going; the digging of a canal by Israel, short-circuiting the Suez Canal; the drying up of remittances from emigrants, who returned from the Gulf after oil became useless due to an American chemist's invention of a product called Pyrol in 2010. ${ }^{6}$ The discovery of this petroleum substitute, which reduced the price of oil to only slightly more than that of water, accelerated Egypt's decline. In order to ensure a supply of Pyrol, the elites sold their past, pawning the entirety of Egypt's Pharaonic monuments to the Americans in exchange for a contract guaranteeing a 50 year supply of Pyrol for the exclusive use of Utopia and other gated communities. Another consequence of this discovery was the expulsion of Egyptian emigrants from the Gulf countries. 'The economy couldn't bear this additional burden, and the state washed its hands of all responsibility. It stopped all forms of social assistance, privatized everything. There was no more government to take care of us. One day it simply stopped paying salaries and running its services. The police disappeared. In the meantime, the people belonging to your parents' class continued getting richer' (p.99). The disappearance of the middle class and the state led to spatial segregation and the population's descent into almost animal-like violence.

Utopia was constructed in the context of a new regional framework in the Middle East, based on 'money from the Gulf (before it melted away), Israeli know-how, and cheap Egyptian labour' (id.). For the people of Utopia, Israel is not an enemy; only the poor continue to perceive it that way. The narrator claims to have numerous Israeli friends and he mentions the presence of synagogues in Utopia. In 2023, the compound is closed off and dependant on the West for various imports, not just Pyrol, but also Phlogistine, a drug imported from Denmark that all Egyptians, rich or poor, are crazy over, as well as Libidafro, a sort of new Viagra from France. The degree of dependence on the United States is such that in order to ensure their protection, the wealthy residents of Utopia pay retired US Marines, on whose loyalty they can count. 
The dissolution of national identity is a recurrent theme in the novel: 'For sixteen years you've had no other identity but that of a citizen of Utopia. You're a Utopian resident, softened by a life of luxury and boredom. You end up unable to tell and American from an Egyptian from an Israeli. You end up unable to tell yourself apart from other people' (p.14). This erasure of national belonging is accompanied by a loss of memory. The young narrator, although he is educated, no longer remembers the war of $1973^{7}$ and confuses the Vietnam and Iraq wars. Everything about Utopia smacks of Western capitalist influence, in particular that of American cinema. 'It was like the famous old poster for the film Platoon' (p.11) is the book's opening line: the young narrator's observation as he witnesses the killing of an intruder who tried to enter the walled city. The book is full of references to American history. Yet, the narrator develops a sharp sense of belonging to Utopia, like that of an animal to its territory: 'I'm someone who doesn't belong to place or to an individual, or to a principle. In spite of everything, it is the homeland.' (p.157). At the end, as the revolt is afoot and the Marines announce the need to evacuate, he claims indignantly: 'Leave? Emigrate? Never. This is my territory, my universe. I was born here. My father may have stolen these rights, but they are mine by birth and I won't give them up for a bunch of Gabers, beggars, and street women' (p.181).

\section{Prey and Predator}

The book is structured in five chapters, which alternate between two voices entitled Predator and Prey. The Predator, whose name the author does not divulge, ${ }^{8}$ is an egocentric and decadent sixteen year-old, the son of a large industrialist, who is bored to death and decides he wants to experience something powerful by murdering one of Utopia's poor people. He takes a female friend, Germinal, with him but they are quickly found out. Just as they are about to be killed, having been identified as residents of Utopia, Gaber takes them under this wing and manages to convince the crowd that they are just thieves. He then decides to take them home. The odious narrator hardly experiences a redemption through his contact with misery though: he rapes Safeya, Gaber's sister, then kills Gaber once he has driven them back home. He cuts off one of his arms, which he embalms. He has completed his initiation rite: 'I am now a man. I went over to the other side, and brought back an arm' (p.171). In contrast, the other narrator, Gaber, is a prophet of Egypt's downfall. Although he knows it will lead to his death, he chooses not to kill the two people from Utopia despite his hatred for them, since his refusal to employ violence is the only thing connecting him to his humanity. His death and Safeya's rape will be the spark that ignites the flames of revolt. ${ }^{9}$

\section{A visionary novel? ${ }^{10}$}

11 Revolution is mentioned several times in the book, through references to the Iranian revolution of 1979 and the French revolution, with the storming of the Bastille as a recurrent image. However the author gives the impression that it is far from actually happening, since the idea is either derided, ${ }^{11}$ or relegated to the distant future. When the young man from Utopia asks Gaber why he doesn't revolt, he responds that the security apparatus has become so powerful that any would-be rioters are quickly dissuaded. 
12 Towfik's work, which closes with the revolt of the Others as they attack Utopia, is more of a social critique than a strictly political one. Those who are criticized here are the Westernized elites, whose selfishness has led them to sell their country and who have allowed the majority of the population to sink into poverty. Indeed when revolution is envisaged, it is from a social angle: 'Revolutions always start by slitting the throats of the rich' ( $p .99)$; 'If the revolution happens, we'll begin by devouring all their fat, pampered dogs' (p. 76).

13 A number of points of difference exist between the scenario imagined by Towfik and the 25 January 2011 revolution. Poverty, unemployment and social inequalities were certainly among the principal causes of the population's exasperation, but the contestation took an eminently political tone, focused on Mubarak's destitution and the fall of the regime. The middle class had not disappeared, but on the contrary sparked the protests. The youth, whom the media characterized as "Westernized" since they used the internet as a tool of contestation, considered themselves above all to be fiercely Egyptian, while simultaneously deeply anchored in modernity. During the 18 days prior to the President's departure, Tahrir Square overshadowed the countermodel of Utopia: by appropriating a central and symbolic public space, far from the new satellite cities and their gated compounds, Egyptians defied authoritarianism and celebrated the nation's rediscovered unity. The micro-territory of Tahrir, organized like a miniature city, transformed itself into a laboratory for a new society ridded of social, political, religious, generational and gender differences (Pagès-El Karoui, 2014). However, the military coup of July 2013, which was supported by much of the population, was followed by the massacre of numerous opponents who denounced the destitution of the democratically elected Islamist president. The violence of this repression reignited the deep cleavages in Egyptian society that the moment of unanimity in Tahrir served to mask (Pagès-El Karoui, 2012). The threatening shadow of Utopia is visible on the revolution's horizon.

\section{BIBLIOGRAPHY}

Bouhali A., 2008. Les compounds cairotes ou la fabrique d'un nouveau mode d'habiter. Des communautés fermées à la ville privatisée ? Master's dissertation, Supervised by O. Pliez, Lyon, ENS-LSH.

Denis E., 2006. Cairo as Neo-Liberal Capital? From Walled City to Gated communities. In Singerman D., Cairo Cosmopolitan. Politics, culture and urban space in the new globalized Middle East. Cairo, The American University in Cairo Press, p. 47-72.

Florin B., 2012. Les quartiers fermés du Grand Caire. Dimensions urbanistiques et idéologiques d'une forme de ville : nouvelle urbanité ou césure urbaine L'Espace Politique [Online], 17, Accessed 2. http://espacepolitique.revues.org/2393

Jacquemond R., 2013. The Yacoubian Building and its sisters: reflections on readership and written culture in modern Egypt. In Soliman M., El Hamamsy W., Popular Culture in the Middle East and North Africa: A Postcolonial Outlook. New York, Routledge, p. 223-236. 
Pagès-El Karoui D., 2014. 2011. L'odyssée de l'espace public égyptien. In Oualdi M., Pagès-El Karoui D., Verdeil C., Les ondes de choc des révolutions arabes. Beirut, IFPO.

Pagès-El Karoui D., 2012. Géographie du changement social en Égypte. EchoGéo [Online], 21. http://echogeo.revues.org/13204

\section{NOTES}

1. Utopia is the novel's title in Arabic. The use of English words in the titles of Egyptian novels is rare, but increasing (c.f. Ahmed Mourad's detective story, Vertigo, published in 2007). For Arabic readers it evokes the Westernization of the elites (Jacquemond, 2013), both in their daily language, which is riddled with English words, and their lifestyle.

2. Significantly, Utopia was translated into French in 2013, not with the publishing house Actes Sud, which publishes the majority of Egyptian authors, but with Ombres noires, which is specialized in crime and detective stories from countries other than France, particularly countries of the global South.

3. Dystopias flourished in Egyptian literature after 2013 (Basma Abdel Aziz's The Queue, Nael Eltoukhy's Women of Karantina, Mohammed Rabie's Otared) to express the disillusionment towards the outcomes of the 2011 revolutions, which brought more violence and wars than democratic transitions.

4. 'The Utopia mentioned here here is an imaginary place, as are the characters who live in and around it, even though the author knows for certain this place will exist soon. Any resemblance to places and individuals in our present reality is purely coincidental (Towfik, 2013, p. 7).

5. At the same point in time, filmmakers were also denouncing violence against women, whether it was conjugal violence, such as in Sheherazade, Tell me a Story by Yousry Nasrallah, or sexual harassment, such as in the film 678 by Mohammed Diab.

6. The increased exploitation of shale oil may ultimately have consequences very similar to Towfik's description of those resulting from the invention of Pyrol.

7. The novel's only temporal marker is the indication that the story takes place 'fifty years after' the Israeli-Arab war of 1973, which is a way for the author to insist on the centrality of the relationship of conflict with Israel.

8. The narrator justifies this as follows: 'Who am I? My name doesn't matter. What good would be it when nothing distinguishes people from one another?' (id., p.15).

9. The Others attack a Pyrol convoy in the desert. They replace the fuel with dirty water that damages the motors of the planes and cars used in Utopia. The residents get stuck, waiting for reinforcement from American helicopters, when the rebellious mass attacks.

10. In the UK, the novel was marketed as premonitory.

11. 'If revolution ever happened, it wouldn't be for equality, but to answer the demands of those who had been deprived of their natural right to Phlogistine' (id., p.11).

\section{INDEX}

Keywords: Egypt, revolution, literature, gated community, socio and spatial inequalities 
AUTHOR

DELPHINE PAGÈS-EL KAROUI

Dephine Pages, dpages\&@inalco.fr, is a lecturer at the INALCO/USPC. 